\title{
ANALISIS YURIDIS PENDIDIKAN JARAK JAUH DALAM PERSPEKTIF HAK ASASI MANUSIA DALAM UNDANG-UNDANG DASAR NRI 1945 PADA MASA PANDEMI COVID-19 DI INDONESIA (Juridical Analysis of Distance Learning System in Perspective of Human Rights on Constitution 1945 During Covid-19 in Indonesia)
}

\author{
Belinda Gunawan \\ Fakultas Hukum Universitas Katolik Indonesia Atma Jaya \\ belind95@gmail.com; belinda.gunawan@atmajaya.ac.id
}

\begin{abstract}
Distance learning at elementary schools, junior and senior high schools in Indonesia during Covid-19 has made new social problems associated with the right to education. Those social problems happened because of the misconception of distance learning which is generally interpreted as "online learning" system that brought social gap in education in Indonesia. It is juridical-normative research, using secondary data as the sources. The form of research is prescriptive that give a solution to the social problems in the distance learning activity. The result of the research is that the rules about distance learning in Indonesia exist in Laws Number 20 of 2003 on National Education System and the rules under it, which are following Pancasila (The Five National Principles), The Constitution of Republic of Indonesia 1945 and human rights principles. Distance Learning is a learning system that allows people to use many learning sources, using information and communication technology (ICT) system that has a broader sense than online learning. Distance learning which upholds the fulfilment of the right to education. Can be defined as an education that based on Pancasila and Constitution of Republic of Indonesia 1945, which has to be implemented democratically, fair, non-discriminative and honours the human rights, also needs to involve the roles of government, schools and society.
\end{abstract}

Keywords : education; distance learning; ministry of education and culture; right to education.

\begin{abstract}
ABSTRAK
Pelaksanaan pembelajaran jarak jauh (PJJ) di sekolah dasar, sekolah menengah pertama dan sekolah menengah atas pada masa pandemi Covid-19 di Indonesia telah menimbulkan permasalahan sosial baru terkait dengan hak atas pendidikan. Permasalahan sosial tersebut dikarenakan adanya miskonsepsi PJJ yang umumnya diartikan sebagai pembelajaran daring (online) yang berakibat pada timbulnya kesenjangan sosial dalam pendidikan. Penelitian ini merupakan penelitian yuridis normatif dengan menggunakan data sekunder. Bentuk penelitian yaitu penelitian preskriptif untuk memberikan saran atas permasalahan PJJ. Tujuan penulisan ini untuk mengetahui pengertian PJJ dalam hukum positif dan kesesuaiannya dengan hak asasi manusia (HAM) di bidang pendidikan dalam hukum Indonesia, yang bermanfaat bagi institusi pendidikan dan pengenyam pendidikan dasar dan menengah dalam melaksanakan PJJ. Hasil penelitian ini mengungkapkan bahwa PJJ di Indonesia telah memiliki dasar hukum pada UU Nomor 20 Tahun 2003 tentang Sisdiknas dan peraturan-peraturan dibawahnya yang sesuai dengan Pancasila, UUD NRI 1945 dan prinsip-prinsip HAM. PJJ merupakan pembelajaran yang menggunakan berbagai sumber belajar, melalui teknologi komunikasi dan informasi yang lebih luas dari sekedar pembelajaran daring saja sebagaimana yang dipahami oleh masyarakat. PJJ yang menjunjung tinggi pemenuhan hak atas pendidikan dapat diartikan yaitu pendidikan yang berdasarkan Pancasila dan UUD NRI Tahun 1945, dimana pendidikan harus dilaksanakan secara demokratis, berkeadilan, tidak diskriminatif dan menjunjung tinggi HAM, sehingga untuk mewujudkannya perlu melibatkan peran pemerintah, institusi pendidikan dan masyarakat.
\end{abstract}

Kata kunci: pendidikan; pembelajaran jarak jauh; kemendikbud; hak atas pendidikan. 


\section{PENDAHULUAN}

Pelaksanaan pembelajaran jarak jauh di sekolah dasar, sekolah menengah pertama dan sekolah menengah atas di tahun 2020 telah menimbulkan permasalahan sosial baru di Indonesia terkait dengan hak atas pendidikan. Seiring dengan berkembangnya teknologi, Indonesia pun sudah mengenal sistem pembelajaran jarak jauh yang diatur dalam peraturan perundang-undangan. Sistem pembelajaran jarak jauh ini diharapkan menjadi alternatif kegiatan pembelajaran ketika pengajar dan siswa tidak bisa bertatap muka secara langsung di dalam kelas.

Permasalahan baru muncul sejak wabah Covid-19 melanda Indonesia pada Maret 2020 lalu, dimana sistem pembelajaran jarak jauh yang sebelumnya merupakan sebuah alternatif berubah menjadi suatu kewajiban yang harus dilaksanakan oleh institusi pendidikan, sesuai dengan kebijakan pemerintah untuk mencegah penyebaran virus. Per Maret 2020, UNESCO mengungkapkan bahwa banyak negara telah menutup sekolah untuk menghindari penyebaran Covid-19 di kalangan pelajar yang berpotensi berdampak luas, ${ }^{1}$ dan hal ini dilakukan juga di Indonesia. Permasalahan ini selanjutnya menjadi fokus penelitian dalam penulisan ini.

Terdapat referensi berupa penelitian terdahulu yang memiliki keterkaitan dengan penelitian ini. Adapun penelitian terdahulu yang pernah dilakukan oleh para peneliti sebelumnya diantaranya yaitu berjudul "Pendidikan Jarak Jauh" yang dilakukan oleh Aria Jalil pada tahun 1994, yang memperlihatkan bahwa pendidikan jarak jauh (PJJ) memberikan kesempatan untuk peningkatan mutu pendidikan yang sesuai dengan perkembangan IPTEK, namun dalam penerapannya harus memperhatikan faktor kesiapan antara semua pihak yang berkepentingan demi tercapainya efektivitas PJJ. ${ }^{2}$ Kemudian terdapat penelitian mengenai efektivitas PJJ dalam artikel Efektivitas Pembelajaran Jarak Jauh Terhadap Pembelajaran Siswa di SDIT Cendektia Purwakarta oleh Anggy Giri Prawiyogi et al pada Mei 2020 yang

1 Giovani Dio Prasasti, "UNESCO: Penutupan Sekolah Akibat COVID-19 Berdampak Pada 290 Juta Pelajar Di Dunia Pendidikan," last modified 2020, accessed July 19, 2020, https://www.liputan6.com/health/read/4195275/u nesco-penutupan-sekolah-akibat-covid-19berdampak-pada-290-juta-pelajar-di-dunia. berkesimpulan bahwa PJJ merupakan metode pembelajaran yang cukup efektif sebagai pengganti pembelajaran dengan tatap muka di masa pandemi Covid-19, namun tetap memiliki kendala yang harus dihadapi, seperti permasalahan teknis, dimana ada listrik yang padam atau jaringan internet yang buruk, orang tua yang tidak dapat mendampingi siswa, ataupun siswa yang tidak konsisten dengan jadwal belajar yang ditentukan. ${ }^{3}$

Kebutuhan akan pendidikan tidak boleh terhambat karena kondisi yang tidak kondusif, sehingga meskipun pengajar dan siswa tidak bertatap muka, pembelajaran harus tetap berlanjut. Sejalan dengan era perkembangan teknologi, banyak sekolah-sekolah dasar dan menengah di Indonesia yang menerapkan pembelajaran jarak jauh berbasis dalam jaringan (online) maupun luar jaringan (offline) pada praktiknya. Kementerian Pendidikan dan Kebudayaan (Kemendikbud) bersama Kementerian Kesehatan (Kemenkes), Kementerian Dalam Negeri (Kemendagri), Kementerian Agama (Kemenag) telah mengeluarkan Surat Keputusan Bersama (SKB) tentang Panduan Pembelajaran Pada Tahun Ajaran Baru dan Tahun Akademik Baru di Masa Pandemi Covid-19 memungkinkan pembelajaran tatap muka di kabupaten/kota yang merupakan zona hijau menurut Gugus Tugas Percepatan Penanganan Covid-19 Nasional dengan memperhatikan protokol kesehatan. Namun untuk daerah-daerah yang masih berada di zona yang tidak hijau, pembelajaran dapat tetap dilakukan melalui jarak jauh sesuai dengan kebijakan kepala daerah. Selain itu kepala sekolah diberikan hak untuk menentukan apakah sekolah tersebut sudah siap untuk mengadakan pembelajaran tatap muka, dan orang tua siswa yang merasa tidak siap jika anaknya harus kembali bersekolah karena kekhawatiran akan penyebaran virus, berhak menolak

\footnotetext{
2 Aria Jalil, "Pembelajaran Jarak Jauh," Jurnal Ilmu Pendidikan Universitas Negeri Malang 1, no. 1 (1994): 22-43.

3 Anggy Giri Prawiyogi et al., "Efektivitas Pembelajaran Jarak Jauh Terhadap Pembelajaran Siswa Di SDIT Cendektia Purwakarta," Jurnal Pendidikan Dasar UNJ 11, no. 1 (2020).
} 
pembelajaran tatap muka dan melanjutkan pembelajaran dari rumah. ${ }^{4}$

Untuk menunjang pembelajaran jarak jauh, pemerintah pun telah menyiapkan setidaknya 12 aplikasi pembelajaran daring gratis yang dapat diakses dari ponsel ataupun komputer pengguna, ${ }^{5}$ serta menggandeng TVRI dalam menyiarkan program Belajar Dari Rumah yang dapat ditonton langsung di televisi ataupun streaming bagi para siswa PAUD, Sekolah Dasar (SD), Sekolah Menengah Pertama (SMP), hingga Sekolah Menengah Atas (SMA) sederajat yang tidak dapat pergi ke sekolah karena terdampak Covid-19. ${ }^{6}$

Adapun pada Peraturan Menteri Pendidikan dan Kebudayaan (Permendikbud) Nomor 119 Tahun 2014 tentang Penyelenggaraan Pendidikan Jarak Jauh Pada Jenjang Pendidikan Dasar dan Menengah, diatur bahwa pendidikan jarak jauh menggunakan berbagai sumber belajar melalui penerapan prinsip-prinsip teknologi pendidikan/pembelajaran. ${ }^{7}$ Kerap kali frasa "penerapan prinsip-prinsip teknologi" ini kemudian yang seringkali diartikan sebagai penerapan pembelajaran daring menggunakan perangkat keras dan aplikasi perangkat lunak oleh masyarakat. Padahal, apakah sebenarnya peraturan perundang-undangan memiliki konsep PJJ yang demikian?

Berbagai peraturan perundang-undangan dan kebijakan yang ada ini telah memperlihatkan bahwa negara hadir dalam menyukseskan program pendidikan melalui berbagai program jarak jauh yang telah disediakan, akan tetapi di tengah kemudahan tersebut, ternyata masih terdapat permasalahan lain yang dialami pada praktiknya. Misalnya akses internet yang belum terjangkau di daerah-daerah pelosok, guru yang

4 Kementerian Pendidikan dan Kebudayaan RI, "Mendikbud Kembali Tegaskan Pembukaan Sekolah Di Zona Hijau Harus Mengedepankan Protokol Kesehatan," last modified 2020, accessed July 19 , 2020 , https://www.kemdikbud.go.id/main/

5 Albertus Adit, "12 Aplikasi Pembelajaran Daring Kerjasama Kemendikbud, Gratis!," last modified 2020, accessed July 19, 2020, https://edukasi.kompas.com/read/2020/03/22/123 204571/12-aplikasi-pembelajaran-daringkerjasama-kemendikbud-gratis?page $=$ all.

6 CNBC Indonesia, "Nonton TVRI Online \& Jadwal Belajar Dari Rumah Anak Sekolah," last modified April 14, 2020, accessed July 19, 2020, https://www.cnbcindonesia.com/tech/2020041414 belum menguasai cara penggunaan aplikasi daring, orang tua yang bekerja sehingga tidak dapat mendampingi anak untuk belajar dari rumah, atau tingginya biaya yang digunakan untuk melihat siaran pendidikan dari televisi ataupun membeli perangkat keras dan membayar akses internet memberatkan siswa yang kurang mampu secara finansial. Berbagai kendala yang dialami oleh penyelenggara pendidikan maupun peserta didik tersebut dapat mengakibatkan tidak dapat terpenuhinya hak-hak asasi manusia, khususnya hak atas pendidikan.

HAM berlaku universal sebagaimana diungkapkan dalam Pasal 2 UDHR yang menyatakan bahwa HAM dimiliki oleh semua orang tanpa membedakan menurut ras, warna kulit, jenis kelamin, bahasa, agama, pendapat politik, asal-usul nasional atau sosial, kekayaan, kelahiran atau status lain. Namun pada realitanya, kenyataan memperlihatkan bahwa semua orang tidak sama, dalam kesempatan mengembangkan diri, tidak sama kedudukan sosialnya, kepandaiannya atau kekayaannya. ${ }^{8}$ Kenyataan ini pun yang merefleksikan bahwa tidak semua warga negara dapat mendapatkan pendidikan secara layak. Oleh karena itu, keberadaan hukum diperlukan untuk melindungi dan memenuhi hak-hak atas pendidikan bagi para warga negaranya, karena sebagai negara hukum yang mengakui HAM, Indonesia harus menerapkan hukum yang sesuai dengan perlindungan HAM, namun tetap dengan memperhatikan Pancasila yang menjadi volksgeist atau "jiwa bangsa" Indonesia, supaya pengembangan hukum nasional dalam konstitusi dapat menjadi lebih lengkap, komprehensif dan sesuai dengan kepribadian bangsa Indonesia

4619-37-151832/nonton-tvri-online-jadwalbelajar-dari-rumah-anak-sekolah.

7 Menteri Pendidikan dan Kebudayaan RI, Peraturan Menteri Pendidikan Dan Kebudayaan Nomor 119 Tahun 2014 Tentang Penyelenggaraan Pendidikan Jarak Jauh Pada Jenjang Pendidikan Dasar Dan Menengah, 2014.

8 Rhona K.M. Smith et al., Hukum Hak Asasi Manusia, 3rd ed. (Yogyakarta: PUSHAM UII, 2015), hlm. xii.

9 RM A.B. Kusuma, Sistem Pemerintahan Pendiri Negara versus Sistem Presidensiel Orde Reformasi (Depok: Badan Penerbit Fakultas Hukum Universitas Indonesia, 2011). 
yang menjunjung tinggi kesetaraan, ${ }^{10}$ mencakup kesetaraan bidang sosial, politik, ekonomi dan kebudayaan.

Berdasarkan uraian permasalahan tersebut, maka rumusan masalah dalam penelitian ini adalah:

1. Bagaimana pengaturan pembelajaran jarak jauh diatur di Indonesia?

2. Bagaimana kesesuaian regulasi pendidikan jarak jauh dengan pengaturan hak asasi manusia di bidang pendidikan dalam konstitusi Indonesia?

\section{METODE PENELITIAN}

Bentuk dalam penelitian ini adalah penelitian yuridis normatif, yaitu penelitian yang digunakan untuk menjawab permasalahanpermasalahan yang telah diuraikan sebelumnya berdasarkan asas-asas hukum, ${ }^{11}$ dimana permasalahan dalam penelitian ini adalah analisis regulasi pendidikan jarak jauh dalam perspektif HAM untuk mewujudkan keadilan sosial yang berdasarkan Pancasila, pada masa terjadinya terjadinya wabah Covid-19 di Indonesia. Pengumpulan data dilakukan dengan studi kepustakaan atau library research. Jenis data yang digunakan dalam penelitian adalah data sekunder, yaitu data yang diperoleh dari bahanbahan kepustakaan. ${ }^{12}$ Data sekunder dalam penulisan ini terdiri dari bahan hukum primer, bahan hukum sekunder dan bahan hukum tersier, yang meliputi Undang-Undang Dasar Negara Republik Indonesia 1945 dan perubahannya, UU Nomor 39 Tahun 1999 tentang Hak Asasi Manusia, UU Nomor 20 Tahun 2003 tentang Sistem Pendidikan Nasional dan peraturan perundang-undangan lain yang relevan dengan penulisan ini.

Alat pengumpulan data adalah melalui penelusuran literatur atau studi dokumen. Metode analisis data dilakukan dengan pendekataan kualitatif, yaitu metode yang menghasilkan data berupa uraian mengenai apa yang dinyatakan oleh sasaran penelitian, dan kebenaran data atau premis akhir penelitian ditentukan oleh penelitinya sendiri. Sedangkan tipologi penulisan

10 Ilham Yuli Isdiyanto, “Menakar 'Gen' Hukum Indonesia Sebagai Dasar Pembangunan Hukum Nasional," Jurnal Hukum dan Pembangunan 48, no. 3 (2018): 589-611.

11 Johnny Ibrahim, Teori Dan Metodologi Penelitian Hukum Normatif(Malang: Bayumedia Publishing, 2008), hlm. 301. ini tergolong dalam penulisan preskriptif, yaitu ditujukan untuk mendapatkan saran-saran mengenai apa yang harus dilakukan untuk mengatasi masalah-masalah tertentu. ${ }^{13}$ Saran yang akan diberikan yaitu mengenai langkahlangkah yang dapat dilakukan oleh pemerintah dan masyarakat untuk mewujudkan pendidikan jarak jauh yang sesuai dengan prinsip-prinsip HAM sebagaimana diatur dalam UUD NRI 1945 yang merupakan konstitusi Indonesia.

\section{PEMBAHASAN}

\section{A. Hak Warga Negara Atas Pendidikan dan Peran Negara Dalam Memajukan Pendidikan}

Pendidikan merupakan hak dasar yang diatur dalam konstitusi, sebagaimana disebutkan dalam UUD 1945 yang telah diamandemen, tepatnya Pasal 28C ayat (1) dan (2) yang mengatur bahwa Setiap orang berhak mengembangkan diri melalui pemenuhan kebutuhan dasarnya, berhak mendapat pendidikan dan memperoleh manfaat dari ilmu pengetahuan dan teknologi, seni dan budaya, demi meningkatkan kualitas hidupnya dan demi kesejahteraan umat manusia serta Pasal 31 ayat (1) dan (2) yang menyebutkan bahwa setiap warga negara berhak mendapatkan pendidikan, wajib mengikuti pendidikan dan negara wajib membiayainya. ${ }^{14}$ Kemudian pada Pasal 31 ayat (5) UUD 1945 disebutkan bahwa pemerintah memajukan ilmu pengetahuan dan teknologi dengan menjunjung tinggi nilai-nilai agama dan persatuan bangsa untuk kemajuan peradaban serta perkembangan umat manusia. Dari rumusan pasal tersebut diketahui bahwa pendidikan merupakan hak setiap warga negara yang harus diperhatikan oleh pemerintah.

Selain itu, dalam Pasal 12 UU Nomor 39 Tahun 1999 tentang HAM disebutkan bahwa setiap orang berhak atas perlindungan bagi pengembangan pribadinya, untuk memperoleh pendidikan, mencerdaskan dirinya, dan

12 Soerjono Soekanto and Sri Mamudji, Penelitian Hukum Normatif: Suatu Tinjauan Singkat (Jakarta: Rajawali Pers, 2013), hlm. 401.

13 Ibid.

14 Republik Indonesia, Undang-Undang Dasar Negara Republik Indonesia 1945 (Setelah Amandemen). 
meningkatkan kualitas hidupnya. ${ }^{15}$ Ketentuanketentuan inilah yang menjadi dasar atas kesetaraan hak warga negara, khususnya anakanak Indonesia untuk mendapatkan pendidikan yang layak dan pengembangan diri sebebasbebasnya demi menata masa depan yang lebih baik. ${ }^{16}$

Rumusan dalam berbagai undang-undang ini selaras dengan Pasal 26 Universal Declaration of Human Rights (UDHR) yang berbunyi: ${ }^{17}$

"Everyone has the right to education. Education shall be free, at least in the elementary and fundamental stages. Elementary education shall be compulsory. Technical and professional education shall be made generally available and higher education shall be equally accessible to all on the basis of merit," yang apabila diterjemahkan berarti sebagai berikut:

"Setiap orang berhak memperoleh pendidikan. Pendidikan hendaklah cuma-cuma, setidaktidaknya untuk tingkatan sekolah dasar dan tingkat fundamental. Pendidikan dasar harus diwajibkan. Pendidikan teknik dan kejuruan secara umum harus terbuka bagi semua orang, dan pendidikan tinggi harus dapat dimasuki dengan cara yang sama oleh semua orang, berdasarkan prinsip merit."

Prinsip merit atau sistem merit yang dikenal saat ini berasal dari istilah "meritokrasi" yang dipopulerkan oleh Michael Young pada tahun 1958, yang berarti "sebuah pandangan atau pemberian peluang kepada orang untuk maju berdasarkan kelayakan dan kecakapannya atau kecemerlangan." 18 Sistem merit pada saat ini biasa dihubungkan dengan cara untuk memperoleh jabatan tertentu dalam sebuah organisasi atau hirarki kepegawaian, namun sebenarnya sistem merit tidak sebatas berlaku dalam manajemen pegawai, melainkan pengertian yang lebih luas, yaitu pemberian peluang secara objektif untuk mendapatkan status tertentu beserta hak-hak dan kewajiban di dalamnya, termasuk status sebagai pelajar

15 Republik Indonesia, Undang-Undang No. 39 Tahun 1999 Tentang Hak Asasi Manusia, 1999.

16 Abdul Rozak, "Perlindungan Hak Atas Pendidikan Bagi Pengungsi Internal: Studi Kasus Pendidikan Anak Korban Kekerasan Terhadap Warga Syiah Sampang," Juris-Diction 2, no. 6 (2019): 19871908, hlm. 1988.

17 United Nations, "Universal Declaration of Human Rights," 1948. sekolah maupun mahasiswa. Dengan demikian, bahwa dalam persoalan pendidikan, negara yang berdasarkan hukum menghendaki agar setiap orang diberikan hak yang sama untuk mengenyam pendidikan tanpa pembedaan status sosial, kekayaan atau kekerabatan dengan institusi penyelenggara pendidikan.

Maka dari itu, pendidikan dasar haruslah menjadi prioritas yang diutamakan oleh negara, tidak hanya sekedar di dalam aturan hukum, tetapi pada praktik pelaksanaannya. Kemudian, sistem pendidikan yang diatur di dalam undang-undang harus sesuai dengan grundnorm yang telah disepakati oleh para pendiri negara (the founding fathers), yaitu Pancasila yang telah diikrarkan dalam Pembukaan UUD 1945. Kesesuaian undang-undang dengan grundnorm merupakan suatu keharusan, sebagai konsekuensi sebab grundnorm ada karena hirarki norma hukum berakhir di tingkat norma yang paling tinggi, dan norma tertinggi tersebut merupakan dasar validitas norma hukum di bawahnya. ${ }^{19}$

Pendiri negara Indonesia bermaksud membentuk negara kesejahteraan (welfarestate), dan bukan negara penjaga malam (nightwatchmenstatel nachwachterstaat), ini berarti bahwa negara kesejahteraan adalah bentuk pemerintahan demokratis yang menegaskan bahwa negara bertanggung jawab terhadap kesejahteraan rakyatnya ${ }^{20}$ sebagaimana tertuang dalam sila Ke-5 yaitu "Keadilan Sosial Bagi Seluruh Rakyat Indonesia" dan tercantum pada pembukaan UUD 1945 yang berbunyi "...untuk memajukan kesejahteraan umum, mencerdaskan kehidupan bangsa, dan ikut melaksanakan ketertiban dunia yang berdasarkan kemerdekaan, perdamaian abadi dan keadilan sosial...”21

Saat ini, dasar hukum pendidikan di Indonesia diatur pada UU Nomor 20 Tahun

18 Farhan Abdi Utama, "Meritokrasi Di Berbagai Negara Dunia," Jurnal Civil Service Badan Kepegawaian Negara 10, no. 2 (2016): 17-27.

19 Hans Kelsen, The Pure Theory of Law (California: University of California Press, 1967), hlm. 193-194.

20 Ibid.

21 Republik Indonesia, Undang-Undang Dasar Negara Republik Indonesia 1945 (Setelah Amandemen). 
2003 tentang Sistem Pendidikan Nasional yang menggantikan UU Nomor 2 Tahun 1989 tentang Sistem Pendidikan Nasional yang dianggap sudah tidak memadai dan tidak relevan dengan kondisi sekarang ini, khususnya setelah amandemen UUD 1945. Dalam konsiderans UU Nomor 20 Tahun 2003, dikatakan sistem pendidikan nasional harus mampu menjamin pemerataan kesempatan pendidikan, peningkatan mutu serta relevansi dan efisiensi manajemen pendidikan untuk menghadapi tantangan sesuai dengan tuntutan perubahan kehidupan lokal, nasional, dan global sehingga perlu dilakukan pembaharuan pendidikan secara terencana, terarah, dan berkesinambungan. Dalam bagian penjelasan juga disebutkan bahwa pendidikan nasional berfungsi mengembangkan kemampuan dan membentuk watak serta peradaban bangsa yang bermartabat dalam rangka mencerdaskan kehidupan bangsa, bertujuan untuk berkembangnya potensi peserta didik agar menjadi manusia yang beriman dan bertakwa kepada Tuhan Yang Maha Esa, berakhlak mulia, sehat, berilmu, cakap, kreatif, mandiri, dan menjadi warga negara yang demokratis serta bertanggung jawab..$^{22}$ Dengan kata lain, undangundang mengamanatkan bahwa bangsa Indonesia tidak hanya dididik untuk menjadi manusia yang intelek dan cerdas, namun juga mengikuti perkembangan dunia dan bermartabat sesuai dengan nilai-nilai bangsa.

Pada Pasal 1 angka 1 UU Nomor 20 Tahun 2003 disebutkan bahwa Pendidikan adalah "usaha sadar dan terencana untuk mewujudkan suasana belajar dan proses pembelajaran agar peserta didik secara aktif mengembangkan potensi dirinya untuk memiliki kekuatan spiritual keagamaan, pengendalian diri, kepribadian, kecerdasan, akhlak mulia, serta keterampilan yang diperlukan dirinya, masyarakat, bangsa dan negara." Selanjutnya pada angka ke-2, disebutkan bahwa Pendidikan Nasional adalah pendidikan yang berdasarkan Pancasila dan Undang-Undang Dasar Negara Republik Indonesia Tahun 1945 yang berakar pada nilainilai agama, kebudayaan nasional Indonesia dan

22 Republik Indonesia, Undang-Undang Nomor 20 Tahun 2003 Tentang Sistem Pendidikan Nasional, 2003.

23 Ibid, Ps.1.

24 Hasmiati Sessu, "Evaluasi Penyelenggaraan Pendidikan Jarak Jauh Bagi Tenaga Bidan Lulusan Diploma I Kebidanan Di Poltekkes Kemenkes Kupang Tahun 2015" (Universitas Indonesia, 2015), hlm. 8. tanggap terhadap tuntutan perubahan zaman. ${ }^{23}$ Oleh karena itu, dihubungkan dengan keadaan saat ini, dimana Indonesia menghadapi era globalisasi, maka pendidikan di Indonesia harus tetap mencerminkan jati diri bangsa, yaitu Pancasila namun tetap tangguh dalam mengikuti perkembangan teknologi yang berkembang pesat.

\section{B. Penyelenggaraan Pembelajaran Jarak Jauh di Indonesia dalam Literatur dan Peraturan Perundang-Undangan}

Pengertian pembelajaran jarak jauh dapat ditemukan dari beberapa literatur antara lain oleh Schlosser dan Simonson dalam Teaching and Learning at a Distance (2012) yang mendefinisikan pendidikan jarak jauh sebagai proses pengajaran dimana sebagian besar proporsi pembelajarannya dilakukan oleh seseorang (pengajar) yang terpisah dengan peserta belajar baik dari sisi jarak maupun waktu. ${ }^{24}$ Mc Kenzie merumuskan pembelajaran jarak jauh sebagai suatu metode pembelajaran yang dilakukan dengan menggunakan korespondensi sebagai alat komunikasi antara pengajar dengan siswa di tambah dengan adanya interaksi antar siswa didalamnya. ${ }^{25}$ Moore lebih lanjut menambahkan pengertian pembelajaran jarak jauh sebagai proses pengajaran yang terjadi secara terpisah dari proses belajar sehingga komunikasi antara tenaga pengajar dan siswa harus difasilitasi melalui bahan cetak, media elektronik, dan media-media lain. ${ }^{26}$

Pembelajaran jarak jauh itu sendiri sebenarnya dikembangkan sebagai sebuah upaya untuk mengatasi masalah pendidikan berupa adanya keterbatasan antara pengajar (tutor) dengan peserta didik untuk bertatap muka dengan mengadakan pembelajaran yang memisahkan antara tenaga pengajar dengan peserta didik dengan bantuan media cetak maupun elektronik seperti email, video konverensi, softfile yang berisi materi yang dapat diakses oleh peserta didik tanpa adanya batasan waktu dan letak geografis. Dan semua

25 O. MacKenzie, E. Christensen, and Rigby P.H., Correspondence Instruction in the United States: A Study of What It Is, How It Functions, and What Its Potential May Be. (New York: McGraw-Hill Book Co., 1968).

26 M.G. Moore, "Toward a Theory of Independent Learning and Teaching," Journal of Higher Education 44 (1973): 66-79. 
itu dikoordinir oleh lembaga penyelenggara pendidikan jarak jauh untuk melakukan perencanana, pengorganisasian, dan monitoring terhadap berjalannya proses pendidikan jarak jauh itu sendiri. ${ }^{27}$

Mekanisme pendidikan jarak jauh sebagaimana dijelaskan tersebut pada dasarnya telah diterapkan sejak lama di Indonesia. Awal pekembangan pembelajaran jarak jauh di indonesia dimulai sejak tahun 1950 oleh pemerintah dengan membentuk sebuah lembaga Balai Kursus Tertulis Pendidikan Guru (BKTPG) yang mendapat tugas untuk meningkatkan kemampuan pengajar dalam mengajar. Proses pembelajarannya dengan menyediakan berbagai paket belajar tertulis dalam bidang profesi kependidikan. Pendidikan jarak jauh kemudian dalam perkembangannya dituangkan dalam kebijakan GBHN dengan digunakannya siaran radio dan televisi dalam memeratakan pendidikan dan meningkatkan mutu pendidikan. $^{28}$

Sebagai lembaga yang netral, tidak berpihak, berdiri di atas semua golongan masyarakat dan mengabdi pada kepentingan umum, Indonesia sebagai negara hukum menghendaki segala tindakan atau perbuatan penguasa mempunyai dasar hukum yang jelas atau ada legalitasnya baik berdasarkan hukum tertulis maupun berdasarkan hukum tidak tertulis, ${ }^{29}$ oleh sebab itu, penyelenggaraan pembelajaran jarak jauh pun diatur berdasarkan norma-norma dalam hukum positif Indonesia.

Peraturan yang mengatur tentang pendidikan jarak jauh (PJJ) diantaranya UU Nomor 20 Tahun 2003 tentang Sistem Pendidikan Nasional, PP Nomor 17 Tahun 2010 tentang Pengelolaan dan Penyelenggaraan Pendidikan serta Permendikbud Tahun 119 Tahun 2014 tentang Penyelenggaraan Pendidikan Jarak Jauh Pada Jenjang Pendidikan Dasar dan Menengah. Dengan demikian, diketahui bahwa sistem PJJ telah diatur di Indonesia bahkan sebelum adanya pandemi Covid-19, namun sistem ini hanya bersifat alternatif yang menjadi

27 Irfan Rahman Nurdin, "Penerapan Sistem Pembelajaran Jarak Jauh Berbasis Massive Open Online Course (MOOC) Di Universitas Ciputra Enterpreunership Online (UCEO)" (Universitas Negeri Semarang, 2017).

28 Munir, Pembelajaran Jarak Jauh Berbasis Teknologi Informasi Dan Komunikasi (Bandung: Alfabeta, 2009). pilihan bagi peserta didik maupun institusi pendidikan untuk dilaksanakan atau tidaknya.

Tetapi setelah Covid-19 menyebar di Indonesia sejak bulan Maret 2020 yang lalu, pemerintah menutup sekolah-sekolah untuk mencegah penyebaran virus, terutama sekolah yang berada di zona merah, sehingga proses belajar mengajar dilakukan dari jarak jauh. Hal ini sudah ditegaskan oleh pemerintah, khususnya melalui Surat Edaran Menteri Pendidikan dan Kebudayaan (SE Mendikbud) Nomor 4 Tahun 2020 tentang Pelaksanaan kebijakan Pendidikan dalam Masa Darurat Penyebaran Covid-19 dan Surat Edaran Sekretaris Jenderal Kementerian Pendidikan dan Kebudayaan (SE Sekjen Kemendikbud) Nomor 15 Tahun 2020 Pedoman Penyelenggaraan Belajar dari Rumah dalam Masa Darurat Penyebaran Covid-19 memperjelas tentang tata cara pelaksanaan pendidikan jarak jauh.

Pada Pasal 1 angka 15 UU Nomor 20 Tahun 2003, disebutkan bahwa Pendidikan jarak jauh adalah pendidikan yang peserta didiknya terpisah dari pendidik dan pembelajarannya menggunakan berbagai sumber belajar melalui teknologi komunikasi, informasi, dan media lain. ${ }^{30}$ Selanjutnya PP Nomor 17 Tahun 2010 tentang Pengelolaan dan Penyelenggaraan Pendidikan, menyebutkan kembali definisi yang sama, yaitu PJJ sebagai "pendidikan yang peserta didiknya terpisah dari pendidik dan pembelajarannya menggunakan berbagai sumber belajar melalui teknologi komunikasi, informasi, dan media lain." ${ }^{31}$ Kemudian dalam peraturan turunannya, Peraturan Menteri Pendidikan dan Kebudayaan (Permendikbud) Nomor 119 Tahun 2014 tentang Penyelenggaraan Pendidikan Jarak Jauh Pada Jenjang Pendidikan Dasar dan Menengah, disebutkan bahwa pendidikan jarak jauh menggunakan berbagai sumber belajar melalui

29 Arief Budiman, Teori Negara: Negara, Kekuasaan Dan Ideologi (Jakarta: Gramedia Pustaka Utama, 1996), hlm.1.

30 Republik Indonesia, Undang-Undang Nomor 20 Tahun 2003 Tentang Sistem Pendidikan Nasional.

31 Republik Indonesia, Peraturan Pemerintah Nomor 17 Tahun 2010 Tentang Pengelolaan Dan Penyelenggaraan Pendidikan, 2010, Ps. 1. 
penerapan prinsip-prinsip teknologi pendidikan/pembelajaran. ${ }^{32}$

Berdasarkan pengertian-pengertian tersebut, tidak disebutkan bahwa pembelajaran yang berbasis teknologi komunikasi dan informasi mewajibkan menggunakan perangkat lunak tertentu maupun kewajiban pembelajaran bertatap muka secara daring ataupun menggunakan platform tertentu, justru UU Nomor 20 Tahun 2003 dan Permendikbud Nomor 119 Tahun 2014 memberikan kebebasan untuk menggunakan berbagai sumber belajar, sesuai dengan kondisi pada masing-masing institusi pendidikan dan siswa. Dengan demikian, buku pelajaran elektronik, modul, siaran televisi dan siaran radio dapat dijadikan sebagai pilihan siswa maupun sekolah untuk pembelajaran jarak jauh.

Bahkan lebih jauh lagi ketentuan Pasal 12 Permendikbud Nomor 119 Tahun 2014 sendiri menyatakan bahwa mekanisme pelaksanaan pembelajaran melalui pendidikan jarak jauh dapat dilaksanakan dengan pemberian penugasan, pengumpulan, dan penilaian tugas baik secara online (dalam jaringan/daring) maupun offline (luar jaringan/luring), ${ }^{33}$ oleh karena itu, sudah seharusnya penyelenggaraan pembelajaran disesuaikan dengan keadaan tiaptiap institusi pendidikan dan kemampuan para peserta didik dalam mengakses pembelajaran serta penugasan yang diberikan.

\section{Regulasi Pembelajaran Jarak Jauh dalam Rangka Pemenuhan Hak Konstitusional Warga Negara Indonesia Atas Pendidikan Pada Masa Terjadinya Covid-19}

Indonesia telah mengatur secara cukup jelas tentang hak-hak asasi manusia di dalam hukum dasar negara Indonesia, yaitu UUD NRI 1945 khususnya pada amandemen kedua. Hakhak yang diatur mencakup pula hak-hak warga negara untuk memperoleh dan memilih pendidikan dan pengajaran yang merupakan bagian dari kelompok hak-hak politik, ekonomi,

32 Menteri Pendidikan dan Kebudayaan RI, Peraturan Menteri Nomor 119 Tahun 2014 Tentang Penyelenggaraan Pendidikan Jarak Jauh Pada Jenjang Pendidikan Dasar Dan Menengah, 2014.

33 Ibid., Ps. 12.

34 Jimly Asshiddiqie, Pengantar Ilmu Hukum Tata Negara, 1st ed. (Jakarta: Rajawali Pers, 2013), hlm. 363.

35 Ibid, hlm. 365. sosial dan budaya. ${ }^{34}$ Kerangka konsep hukum hak asasi manusia (Hukum HAM) yang dimaksud dalam tulisan ini yaitu Hukum HAM dalam konstitusi Indonesia, yaitu normanorma yang menjadi landasan hukum dalam upaya pemenuhan dan perlindungan HAM warga negara Indonesia, termasuk menjadi dasar untuk pembentukan peraturan perundang-undangan di bawah undangundang dasar yang mengatur lebih lanjut tentang HAM. Hukum HAM dalam konstitusi Indonesia tidak hanya membahas hak-hak warga negara dan kewajiban pemerintah untuk memenuhinya, tetapi juga seimbang dengan pelaksanaan kewenangan-kewenangan konstitusional yang dimiliki oleh organorgan negara dan timbal baliknya dengan kewajiban-kewajiban konstitusional yang wajib ditaati dan dipenuhi oleh setiap warga negara. ${ }^{35}$

Pemenuhan hak atas pendidikan pada masa pandemi Covid-19 di Indonesia berbeda dengan kondisi normal, sebab pendidikan dilakukan tidak sepenuhnya di sekolah atau di kelas, tetapi dengan metode lain. Dalam Surat Keputusan Bersama (SKB) Panduan Pembelajaran Tahun Akademik Baru di Masa Pandemi Covid-19, disebutkan bahwa kesehatan dan keselamatan peserta didik, pendidik, tenaga kependidikan, keluarga, dan masyarakat merupakan prioritas utama dalam menetapkan kebijakan pembelajaran. Pada surat keputusan tersebut, ditetapkan bahwa tahun ajaran baru tahun 2020/2021 dimulai pada bulan Juli 2020, dimana untuk daerah yang berada di zona kuning, oranye dan merah tetap melanjutkan belajar dari rumah, sehingga dengan kata lain dilarang melakukan tatap muka di satuan pendidikan atau sekolah, sedangkan untuk zona hijau, pembelajaran tatap muka dimungkinkan, namun pelaksanaannya harus didasarkan pertimbangan kemampuan peserta didik dan mengikuti protokol kesehatan yang ada. ${ }^{36}$ Kebijakan lain yang dilakukan pemerintah yaitu dengan mengalihfungsikan dana BOS

36 Kementerian Pendidikan dan Kebudayaan et al., "Keputusan Bersama Tanggal 15 Juni 2020 Tentang Panduan Penyelenggaraan Pembelajaran Pada Tahun Ajaran Dan Tahun Akademik Baru Di Masa Pandemi Covid-19," in Keputusan Bersama Tanggal 15 Juni 2020 Tentang Panduan Penyelenggaraan Pembelajaran Pada Tahun Ajaran Dan Tahun Akademik Baru Di Masa Pandemi Covid-19 (Jakarta, 2020). 
untuk mendukung kesiapan satuan pendidikan, dimana uang dapat digunakan untuk pembelian pulsa, paket data, dan/atau layanan pendidikan daring berbayar bagi pendidik dan/atau peserta didik, ataupun digunakan untuk pembayaran guru honorer maupun tenaga kependidikan jika dana masih tersedia. ${ }^{37}$ Pengalihfungsian BOS untuk digunakan pada kebutuhan lain kini telah mempunyai payung hukumnya, dan diharapkan agar siswa dan guru dapat belajar secara daring dan terhubung ke internet pada akhirnya hanya dapat dimanfaatkan oleh mereka yang memiliki alat komunikasi yang canggih dan tinggal di daerah didukung oleh keberadaan jaringan internet, namun belum tentu dapat dinikmati oleh siswa yang kurang mampu, ataupun sekolahsekolah yang berada di daerah-daerah tertinggal, terdepan dan terluar dimana fasilitas teknologi informasi dan komunikasi masih belum dapat dijangkau. Dengan kata lain, kepastian hukum yang diberlakukan kepada seluruh warga negara belum tentu secara otomatis memberikan keadilan dan kebermanfaatan hukum kepada seluruh warga negara.

Sejak dulu, keberadaan hukum tertulis sebagai hukum positif yang mengatur hak-hak dan kewajiban pemerintah dan warga negara memberikan kepastian hukum, namun sering kali kepastian hukum tersebut mengakibatkan tercorengnya rasa keadilan di masyarakat. Kondisi ini mirip dengan yang dulu terjadi pada pemikiran ahli hukum Gustav Radbruch yang awalnya menyatakan bahwa kepastian hukum menempati peringkat paling atas di antara tujuan lainnya, yang kemudian pasca Perang Dunia II, diralat olehnya dengan menempatkan tujuan keadilan di atas kepastian dan kemanfaatan hukum. ${ }^{38}$ Pemikiran Radbruch tersebut seharusnya menjadi refleksi bagi para pembuat peraturan perundang-undangan. Perumusan suatu norma hukum oleh pemegang otoritas demi memberikan kepastian hukum tentu merupakan sesuatu yang baik, namun haruslah mengutamakan keadilan hukum dan memberikan kemanfaatan.

Jika berbicara mengenai pendidikan nasional, sudah terdapat norma-norma hukum tentang HAM di dalam konstitusi Indonesia yang

37 Ibid

38 Irvan Mawardi, Paradigma Baru PTUN Respon Peradilan Administrasi Terhadap Demokrasi (Yogyakarta: Thafa Media, 2016), hlm. 29.

39 Komisi Perlindungan Anak Indonesia, Hanya 8 Persen Guru Yang Paham Gawai Untuk mengatur tentang hak atas pendidikan. Hakhak atas Pendidikan tersebut juga diatur secara lebih rinci dan konkret dalam undang-undang maupun peraturan perundang-undangan lain di bawahnya. Selain sudah terdapatnya normanorma perlindungan dan pemenuhan hak atas pendidikan, kebijakan-kebijakan yang dibuat oleh pemerintah di masa pandemi Covid-19 menunjukan negara yang hadir untuk warganya dengan memberikan berbagai kompensasi dan bantuan untuk menunjang pembelajaran berbasis teknologi informasi. Keaktifan dan inisiatif pemerintah untuk mewujudkan kesejahteraan umum dan mencerdaskan kehidupan bangsa serta melindungi segenap bangsa dan tumpah darah Indonesia dari pandemi Covid-19 memperlihatkan hukum tentang HAM di Indonesia tidak hanya tertulis dalam peraturan perundang-undangan semata, tapi juga dipraktikkan dan terimplementasi dalam setiap kebijakan pemerintah, salah satunya melalui penyelenggaraan PJJ.

Namun pada pelaksanaannya, kebijakan PJJ ini menemui permasalahan dan isu-isu di masyarakat, diantaranya isu tentang teknis PJJ yang dianggap terlalu berfokus kepada proses digitalisasi tanpa memperhatikan kesiapan dan kemampuan masyarakat sehingga mengakibatkan adanya kesenjangan sosial bahkan diskriminasi dalam pendidikan. Kemudian terdapat isu lainnya berupa miskonsepsi konsep PJJ oleh sebagian besar masyarakat di Indonesia.

Komisi Perlindungan Anak Indonesia (KPAI) di bulan April telah melakukan survei kepada guru-guru di 14 provinsi Indonesia sebagai responden, yang hasilnya mengambil kesimpulan bahwa adanya fakta bahwa hanya $8 \%$ guru yang mengerti memakai gawai untuk belajar daring, dengan mayoritas guru yang piawai menggunakan gawai (gadget) sebagai sarana teknologi informasi dan komunikasi yaitu merupakan guru-guru yang berasal dari kota-kota besar, ${ }^{39}$ sementara $92 \%$ guru yang menjadi responden disebutkan tidak piawai menggunakan gawai karena tidak

Pembelajaran Daring (Jakarta, 2020), https://www.kpai.go.id/berita/hanya-8-guruyang-paham-gawai-untuk-pembelajarandaring. 
memberlakukan PJJ melalui pembelajaran daring.

Pernyataan KPAI tersebut ${ }^{40}$ menunjukkan kenyataan lain bahwa terjadi miskonsepsi mengenai hakikat PJJ, yang diartikan sebagai pembelajaran daring semata, sehingga kegiatan pembelajaran yang tidak menggunakan metode daring sering kali dianggap sebagai kasus "tidak terlaksananya" PJJ, padahal PJJ tidaklah selalu harus dilakukan secara daring.

Selain itu, dalam beberapa penelitian ilmiah nasional, ditemukan fakta masih banyak masyarakat maupun media massa yang mengartikan PJJ sebagai hal yang sama dengan pembelajaran daring. ${ }^{41}$ Pada penelitian yang dilakukan oleh Oktariawan tentang Kecemasan Siswa dalam Pembelajaran Daring di Masa Pandemi Covid, diketahui fakta mengenai masyarakat yang sebagian besar tidak salah menafsirkan ketentuan peraturan perundangundangan yang mengatur PJJ dan akhirnya beranggapan bahwa PJJ adalah pembelajaran yang mewajibkan untuk belajar secara daring. ${ }^{42}$ Begitu pula dalam penelitian lain oleh Rigianti, guru yang belum mampu melaksanakan pembelajaran daring pada akhirnya merasa kinerjanya tidak sukses, ${ }^{43}$ oleh karena itu perlu dilakukan evaluasi mengenai sosialisasi kebijakan-kebijakan PJJ yang dalam penerapannya sering kali disalahartikan sebagai "pembelajaran tatap muka secara daring melalui perangkat keras dan aplikasi belajar," sehingga PJJ makna PJJ yang pembelajarannya "menggunakan berbagai sumber belajar melalui penerapan prinsip-prinsip teknologi pendidikan/pembelajaran" sebagaimana diatur dalam UU Nomor 20 Tahun 2003 dan Permendikbud Nomor 119 Tahun 2014 mengalami penyempitan makna, padahal hukum

40 Ibid.

41 Dwi Hardani Oktawirawan, "Faktor Pemicu Kecemasan Siswa Dalam Melakukan Pembelajaran Daring Di Masa Pandemi Covid19," urnal Ilmiah Universitas Batanghari Jambi 2, no. 20 (2020): 541-544, hlm. 541.

42 Ibid.

43 Henry Aditia Rigianti, "Kendala Pembelajaran Daring Guru Sekolah Dasar Di Kabupaten Banjarnegara," Jurnal Elementary School Univeritas PGRI Yogyakarta Indonesia 7, no. 2 (2020): 297-302, hlm. 301.

44 Risqi Ervera Nur Arifah, Sukirman, and Sujalwo, "Pengembangan Game Edukasi Bilomatika Untuk Meningkatkan Hasil Belajar Siswa Pada Mata positif Indonesia telah memberikan ruang bagi penggunaan berbagai sumber belajar.

Pembelajaran tatap muka secara daring belum tentu menjadi solusi utama agar pembelajaran jarak jauh tetap efektif. Dalam sebuah penelitian yang dilakukan, metode guru berceramah selama kegiatan pembelajaran dan siswa hanya menyimak mengikuti guru sebagai pendengar pasif di sekolah tingkat dasar $^{44}$ kuranglah efektif, terutama apabila dilaksanakan dari jarak jauh, yang rentan mengalami gangguan seperti keterbatasan sistem pada perangkat yang digunakan, kuatlemahnya jaringan internet, dan konsentrasi siswa, terutama yang masih anak-anak, tidak akan sebaik saat belajar di kelas. Berdasarkan survey yang telah dilakukan UNICEF pada tanggal 18 Mei hingga 29 Mei 2020 dan 5 hingga 8 Juni 2020 melalui kanal U-Report yang terdiri dari SMS, WhatsApp, dan Facebook Messenger, menerima lebih dari 4.000 tanggapan dari siswa di 34 provinsi di Indonesia menunjukkan bahwa sekitar dua pertiga (66 persen) mengatakan mereka merasa tidak nyaman belajar dari rumah dan mayoritas (87 persen) mengatakan mereka ingin segera kembali ke sekolah, dengan lebih dari setengah (62 persen) populasi mengatakan mereka membutuhkan bantuan untuk kuota internet. ${ }^{45}$

Seharusnya PJJ yang berbasis teknologi dapat menjadi sebuah terobosan bagi sistem pembelajaran yang memacu kreativitas siswa dan guru dalam kegiatan belajar mengajar. Lebih lagi, miskonsepsi yang terjadi bukan hanya dapat memberikan dampak bagi efektivitas kegiatan belajar mengajar, tetapi juga menyebabkan diskriminasi antara siswa yang mampu dan tidak mampu, maupun diskriminasi antara sekolah-sekolah yang

Pelajaran Matematika Kelas 1 SD," Jurnal Teknologi Informasi dan Ilmu Komputer Universitas Brawijaya 6, no. 6 (2019): 617624.

45 UNICEF, "Indonesia: Survei Terbaru Menunjukkan Bagaimana Siswa Belajar Dari Rumah (Hampir 9 Dari 10 Responden Mengatakan Mereka Ingin Segera Kembali Ke Sekolah)," last modified 2020, accessed August 20, 2020,

https://www.unicef.org/indonesia/id/pressreleases/indonesia-survei-terbarumenunjukkan-bagaimana-siswa-belajar-darirumah. 
berada di perkotaan, sekolah-sekolah yang mandiri secara keuangan dengan sekolah-sekolah di daerah yang memerlukan perhatian khusus dari pemerintah, padahal, undang-undang menghendaki agar pendidikan diselenggarakan secara demokratis dan berkeadilan serta tidak diskriminatif dengan menjunjung tinggi hak asasi manusia, nilai keagamaan, nilai kultural, dan kemajemukan bangsa. ${ }^{46}$ Sebagaimana dikemukakan oleh Huijbers, apabila seseorang merasa hak-haknya dicederai, maka yang ia lakukan adalah berupaya mencari keadilan, bukan mencari hukum positif. Dengan adanya kepastian hukum melalui hukum tertulis, belum tentu akan menjamin keadilan karena berbagai faktor, misalnya mungkin saja karena hukumnya dibuat melalui proses atau substansinya yang tidak adil, penegakkan dan penerapan hukumnya belum efektif, norma hukumnya sudah tidak cocok dengan keadaan suatu masyarakat, ataupun karena norma hukum tertulis itu tidak melembaga di masyarakat. Selanjutnya Huijbers yang mengutip pendapat Gustav Radbruch menyebutkan bahwa urutan prioritas pemenuhan tujuan hukum secara berurutan adalah keadilan, kepastian dan kemanfaatan hukum. Kepastian hukum memang perlu dijaga, tetapi terdapat pengecualian apabila terdapat pertentangan antara isi hukum dan keadilan yang begitu besar sehingga tata hukum nampak tidak adil, maka saat itu tata hukum tersebut boleh dilepaskan. ${ }^{47}$ Berkaitan dengan pelaksanaan PJJ, kepastian hukum untuk melaksanakan pendidikan berbasis teknologi informasi dan komunikasi tidak boleh dapat mencederai hak-hak atas pendidikan, terutama pendidikan dasar yang wajib diikuti oleh seluruh warga negara Indonesia.

Di era digitalisasi yang sering disebut era industri 4.0 dimana merujuk pada revolusi industri keempat di benua Eropa, ${ }^{48}$ seakan-akan berbagai ideologi, prinsip, nilai dan kebudayaan dari luar Indonesia dapat menembus batas negara, sering kali juga aspek-aspek kehidupan dan cara pandang kita dalam bermasyarakat dipengaruhi oleh paham-paham asing tersebut yang belum tentu sesuai dengan Pancasila sebagai jiwa bangsa, termasuk dalam bidang

46 Republik Indonesia, Undang-Undang Nomor 20 Tahun 2003 Tentang Sistem Pendidikan Nasional, Ps.4.

47 Theo Huijbers, Filsafat Hukum Dalam Lintasan Sejarah (Yogyakarta: Penerbit Kanisius, 1982).

48 Hoedi Prasetyo and Wahyudi Sutopo, "Industri 4.0: Telaah Klasifikasi Aspek Dan Arah Perkembangan Riset," Jurnal Teknologi dan pendidikan. Misalnya, sistem pendidikan di negara maju berbasis teknologi informasi, tidak serta merta begitu saja dapat diterapkan di Indonesia, karena masing-masing negara mempunyai nilai-nilai dan anggaran keuangan yang berbeda untuk melaksanakan kebijakankebijakannya. Pada era revolusi industri 4.0 ini, memang mau tidak mau, hukum kita dipaksa untuk memberikan ruang bagi teknologi informasi yang semakin berkembang pesat dalam bidang pendidikan, tetapi kita harus menyadari bahwa kesiapan bangsa secara moral, spiritual dan material untuk menghadapi dampak globalisasi merupakan hal yang lebih penting untuk dijadikan pertimbangan dalam pembuatan dan penerapan kebijakan mengenai pendidikan. Faktanya, peraturan perundang-undangan di Indonesia telah memberikan kepastian hukum yang menjamin hak atas pendidikan bagi seluruh rakyat Indonesia, meskipun pada praktiknya masih terdapat kesenjangan sosial dan ekonomi yang menghambat pemenuhan hak-hak tersebut, sehingga kesenjangan itu haruslah segera diatasi.

Menghadapi era ini, baik pemerintah maupun masyarakat harus tetap berpedoman kepada Pancasila, UUD 1945 dan undangundang yang mengatur kehidupan berbangsa. Hal ini dikarenakan sebagaimana kita ketahui, keinginan para pendiri negara Indonesia bermaksud membentuk negara kesejahteraan (welfarestate), dan bukan negara penjaga malam (night watchmen state/nachwachterstaat), ini berarti bahwa negara kesejahteraan adalah bentuk pemerintahan demokratis yang menegaskan bahwa negara bertanggungjawab terhadap kesejahteraan rakyatnya. ${ }^{49}$ Indonesia dalam upaya mewujudkan negata kesejahteraan memiliki semangat gotong royong, mengakui adanya perlindungan HAM dan mempunyai keunikan dibandingkan paham-paham lainnya. Indonesia tidaklah menganut paham komunisme yang memberikan kekuasaan penuh kepada negara untuk membuat kebijakan apapun, termasuk dalam rangka

Informasi (J@TI) UNDIP 13, no. 1 (2018): 1726, hlm. 24.

49 RM A.B. Kusuma, Sistem Pemerintahan Pendiri Negara versus Sistem Presidensiel Orde Reformasi (Depok: Badan Penerbit Fakultas Hukum Universitas Indonesia, 2011), hlm. 108. 
menyejahterakan rakyatnya dalam bidang ekonomi maupun sosial, ataupun tidak juga menganut paham liberalisme yang memisahkan antara urusan kegiatan negara dan pasar, namun berdasarkan kekeluargaan dan memerhatikan keseimbangan antara hak individu dan keadilan sosial.

Pemenuhan hak atas pendidikan di Indonesia yang telah diamanatkan dalam UUD 1945 pun harus berpedoman pada undangundang dan memperhatikan hak-hak dan kewajiban seluruh pihak yang ada di dalamnya, serta selalu menyaring terlebih dahulu tiap-tiap budaya luar yang kita temui sebelum diterapkan sehari-hari. Sebagai contoh, Pasal 5 UU Nomor 20 Tahun 2003 mengatur bahwa setiap warga negara mempunyai hak yang sama untuk memperoleh pendidikan yang bermutu; dan warga negara di daerah terpencil atau terbelakang serta masyarakat adat yang terpencil berhak memperoleh pendidikan layanan khusus, ${ }^{50}$ oleh karena itu, pelaksanaan sebuah kebijakan tidak boleh mengesampingkan hak-hak atas pendidikan yang telah diatur dalam hukum, sehingga institusi pendidikan dalam menerapkan kebijakan bagi para pengajar dan siswa harus memperhatikan keadaan yang sebenarnya. Pada sekolah yang mayoritasnya mengalami kendala pada penggunaan komputer, ponsel maupun internet karena berbagai alasan ekonomi, geografis dan sosial, proses belajar mengajarnya tidak bisa disamakan dengan sekolah-sekolah yang siswa dan gurunya telah mampu secara intelektual dan finansial untuk melakukan pembelajaran berbasis daring dan aplikasi.

Keadilan sosial dalam pemenuhan hak-hak atas pendidikan tidak akan terwujud selama diskriminasi dan tidak meratanya akses atas pendidikan masih tetap ada. Padahal, setiap individu di dunia ini memiliki kedudukan, hak, kewajiban dan kesempatan serta peran yang sama dalam segala aspek kehidupan maupun penghidupan seperti individu lainnya, ${ }^{51}$ termasuk pula kesempatan untuk mendapatkan pendidikan. Pemerintah mempunyai kewenangan untuk membuat peraturan dan melaksanakannya dalam

50 Republik Indonesia, Undang-Undang Nomor 20 Tahun 2003 Tentang Sistem Pendidikan Nasional.

51 Donny Michael, "Penyelenggaraan Pendidikan Tinggi Bagi Penyandang Disabilitas Di Universitas Brawijaya," Jurnal HAM 11, no. 2 (2020): 201-217.

52 Philipus M. Hadjon, “Hukum Administrasi Sebagai Instrumen Hukum Untuk Mewujudkan Good Governance," in Hukum Administrasi Dan rangka memberikan kepastian hukum, serta berkewajiban memberikan keadilan hukum bagi warga negaranya, selain itu memastikan bahwa keberadaan hukum memberikan manfaat bagi pihak-pihak yang menjadi subjek hukumnya.

Sebagaimana berkenaan dengan penyelenggaraan tiga tugas dasar pemerintah, yaitu untuk: ${ }^{52}$ (1) Menjamin keamanan setiap orang dan masyarakat; (2) Mengelola suatu struktur yang efektif untuk sektor publik, sektor swasta dan masyarakat; dan (3) Memajukan sasaran ekonomi, sosial dan bidang lainnya dengan kehendak rakyat, pemerintah memegang peran sentral untuk meluruskan miskonsepsi PJJ sebagai digitalisasi sekolah atau pembelajaran daring yang sudah banyak melekat pada masyarakat. Perlu dilakukan sosialisasi kepada institusi pendidikan, para kepala sekolah dan guru dan orang tua siswa tentang konsep PJJ yang sebenarnya diatur dalam peraturan perundangundangan, sehingga sekolah dapat menyesuaikan metode pembelajaran berbasis teknologi dengan kondisi siswa-siswanya.

Hal ini sebenarnya telah diamanatkan dalam ketentuan SE Sekjen Kemendikbud Nomor 15 Tahun 2020 Pedoman Penyelenggaraan Belajar Dari Rumah dalam Masa Darurat Penyebaran Covid-19 yang secara jelas menyatakan bahwa aktivitas dan penugasan selama Belajar Dari Rumah diselenggarakan secara bervariasi antar daerah, satuan pendidikan, dan peserta didik disesuaikan dengan minat dan kondisi yang dihadapi masing-masing, termasuk mempertimbangkan kesenjangan akses terhadap fasilitas belajar dari rumah. ${ }^{53}$ Mekanisme penyesuaian metode pembelajaran berbasis teknologi misalnya dapat dilakukan pada sekolah-sekolah yang siswa maupun orangtuanya kurang mampu, dengan mengalokasikan anggaran BOS untuk membeli kuota internet atau penyediaan aplikasi dapat dialihkan untuk penyediaan alat tulis bagi siswa untuk mencatat pembelajaran

Good Governance (Jakarta: Penerbit Universitas Trisakti, 2010).

53 Sekretaris Jenderal Kemendikbud RI, Surat Edaran Sekretaris Jenderal Kemendikbud Tentang Pedoman Penyelenggaraan Belajar Dari Rumah Dalam Masa Darurat Penyebaran Covid-19 Nomor 15 Tahun 2020 (Jakarta: Kemendikbud RI, 2020), Bab I . 
di siaran televisi (TVRI) yang menjadi program Kemendikbud, atau dapat digunakan untuk membuat modul/buku pelajaran elektronik yang dapat diakses oleh siswa dan dapat dicetak dan diperbanyak oleh siswa untuk dipelajari di rumah bersama dengan orang tua/wali tanpa harus selalu bergantung pada gadget dan aplikasi.

Hal ini tidak bertentangan dengan UU Nomor 20 Tahun 2003 yang mengatur bahwa Pendidikan diselenggarakan dengan mengembangkan budaya membaca, menulis, dan berhitung bagi segenap warga masyarakat; serta penyelenggaraan pendidikan dengan memberdayakan semua komponen masyarakat melalui peran serta dalam penyelenggaraan dan pengendalian mutu layanan pendidikan, ${ }^{54}$ sebaliknya penyesuaian penerapan teknologi informasi dengan keadaan masyarakat untuk menciptakan sebuah keadilan sosial merupakan hal yang diharapkan oleh pembuat undangundang. Apabila dalam praktiknya, pengutamaan penggunaan teknologi menjadi mengesampingkan keadilan dan pemenuhan hakhak atas pendidikan yang diamanatkan dalam peraturan perundang-undangan yang sedang dilaksanakan, padahal hukumnya tidak bertentangan dengan undang-undang dasar dan dasar negara kita. maka seyogyanya diperlukan evaluasi dan kajian kembali mengenai penerapan hukumnya. Evaluasi yang wajib dilakukan adalah evaluasi pendidikan, kegiatan pengendalian, penjaminan, dan penetapan mutu pendidikan terhadap berbagai komponen pendidikan pada setiap jalur, jenjang, dan jenis pendidikan sebagai bentuk pertanggungjawaban penyelenggaraan pendidikan, sebagaimana diatur dalam UU Nomor 20 Tahun 2003. ${ }^{55}$

Peraturan hukum yang berlaku saat ini sebenarnya telah mengantisipasi kendala-kendala yang mungkin dialami dalam penerapan PJJ pada beberapa daerah di Indonesia yang memiliki keterbatasan infrastruktur di bidang teknologi informasi. Tidak dapat dipungkiri sampai saat ini masih banyak wilayah di Indonesia yang belum dapat menikmati jaringan komunikasi, akses internet bahkan ketersediaan listrik sekalipun. Hal inilah yang mendasari adanya pengaturan dalam SE Sekjen Kemendikbud Nomor 15 Tahun 2020 yang membagi metode pelaksanaan PJJ ke

\footnotetext{
54 Republik Indonesia, Undang-Undang Nomor 20 Tahun 2003 Tentang Sistem Pendidikan Nasional.

55 Ibid, Ps. 1 angka 21.

56 Sekretaris Jenderal Kemendikbud RI, Surat Edaran Sekretaris Jenderal Kemendikbud
}

dalam dua pendekatan yaitu; (1) metode PJJ dalam jaringan (daring) atau online, dan (2) metode PJJ luar jaringan (luring) atau offline. ${ }^{56}$

Surat Edaran ini mengamanatkan satuan pendidikan terkait untuk dapat memilih salah satu dari dua pendekatan tersebut, disesuaikan dengan ketersediaan dan kesiapan sarana dan prasarana yang ada dimasing-masing daerah. Proses pemilihan atas pendekatan yang akan dipilih nantinya harus didahului dengan mekanisme pendataan. SE Sekjen Kemendikbud Nomor 15 Tahun 2020 mewajibkan pemerintah daerah untuk melakukan pendataan, yang mencakup antara lain data ketersediaan akses internet dan listrik, serta data kondisi, kesiapan, dan kebutuhan belajar bagi para peserta didik selama belajar dari rumah. Data sebagaimana dimaksud diantaranya mencakup data jumlah dan sebaran peserta didik yang tidak memiliki akses sarana dan pembelajaran daring maupun luring. ${ }^{57}$ Hasil dari pendataan inilah yang kemudian dapat dipergunakan sebagai dasar pertimbangan untuk memilih pendekatan yang paling tepat untuk diterapkan di masingmasing daerah.

Ketentuan dalam SE Sekjen Kemendikbud Nomor 15 Tahun 2020 sendiri sebenarnya telah membuka peluang untuk dilaksanakannya metode PJJ dengan pendekatan luring (offline) jika dari hasil pendataan yang dilakukan diketahui bahwa penerapan metode PJJ dengan pendekatan daring (online) sulit untuk dilaksanakan. Proses pembelajaran melalui metode PJJ dengan pendekatan luring (offline) dapat dilaksanakan dengan menggunakan beberapa fasilitas antara lain media buku, bahan ajar, dan modul pembelajaran mandiri peserta didik serta menggunakan media televisi dan radio untuk daerah-daerah yang memiliki keterbatasan akses internet namun masih dapat menjangkau sambungan listrik. Selain itu pemerintah daerah maupun satuan pendidikan terkait juga harus merancang mekanisme pendistribusian atas sarana pembelajaran luring tersebut kepada para peserta didik yang tidak memiliki akses untuk melaksanakan pembelajaran secara daring. Dalam

Tentang Pedoman Penyelenggaraan Belajar

Dari Rumah Dalam Masa Darurat

Penyebaran Covid-19 Nomor 15 Tahun 2020.

57 Ibid, Bab II Huruf A angka 3. 
pelaksanaannya pemerintah daerah maupun satuan pendidikan terkait juga dapat bekerja sama dengan perpustakaan daerah, taman bacaan masyarakat, organisasi pemerintah dan non pemerintah lainnya untuk penyediaan modul mandiri dan buku untuk pembelajaran luring. ${ }^{58}$

Mekanisme teknis atas penggunaan fasilitas PJJ secara luring dapat dilaksanakan antara lain dengan menyalurkan media buku, bahan ajar, dan modul pembelajaran secara berkala termasuk didalamnya penugasanpenugasan yang diberikan guru kepada peserta didik dalam interval tertentu misalnya setiap minggu atau setiap bulan. Penyaluran tersebut dapat dilakukan dengan berbagai cara seperti pengiriman melalui pos, pengambilan ke sekolah oleh orang tua, atau cara lain bergantung dari kesepakatan antara guru dan orang tua peserta didik serta menyesuaikan dengan kondisi geografis dan infrastruktur yang ada pada masing-masing daerah. Selanjutnya untuk penyaluran media pembelajaran luring pada interval berikutnya juga dapat dilakukan bersamaan dengan pengumpulan tugas yang telah diselesaikan oleh peserta didik. Pelaksanaan mekanisme ini sendiri tetap dilaksanakan dengan memperhatikan prosedur pencegahan penyebaran Covid-19. Upaya untuk mendorong pelaksanaan PJJ dengan pendekatan luring ini, khususnya pada daerah-daerah yang memiliki keterbatasan atas akses internet, dapat menjadi metode alternatif bagi pelaksanaan pendidikan jarak jauh yang dapat menjangkau para peserta didik yang memiliki hambatan-hambatan dalam mengakses teknologi informasi.

Pendidikan jarak jauh yang dapat dikatakan sesuai dengan upaya pemenuhan hak atas pendidikan di Indonesia pada masa terjadinya covid-19 adalah pendidikan berbasis teknologi yang berpedoman pada nilai-nilai Pancasila, terutama keadilan sosial, dan berpedoman pada UUD NRI 1945 maupun asasasas dalam UU Nomor 20 Tahun 2003, yaitu Pendidikan yang memberi keteladanan, membangun kemauan, dan mengembangkan kreativitas peserta didik dalam proses pembelajaran serta tidak diskriminatif. ${ }^{59}$ Argumentasi ini didasarkan pada teori stuffenbau

58 Ibid., Bab II Huruf B angka 3-5.

59 Republik Indonesia, Undang-Undang Nomor 20 Tahun 2003 Tentang Sistem Pendidikan Nasional.

60 Jimly Asshiddiqie, Pengantar Ilmu Hukum Tata Negara, 1st ed. (Jakarta: Rajawali Pers, 2013), hlm. 104. des rechts yang dikembangkan oleh Hans Kelsen, yang menyebutkan bahwa grund norm atau norma dasar adalah norma yang menjadi dasar terbentuk dan berlakunya norma hukum lainnya, dimana norma yang lebih rendah tidak boleh bertentangan dengan norma yang lebih tinggi, oleh karena itu, dalam kasus pelaksanaan PJJ di Indonesia, Pancasila sebagai grundnorm yang nilai-nilainya dijabarkan dalam pasal-pasal UUD NRI 1945 harus menjadi acuan pokok bagi pemerintah, institusi Pendidikan maupun masyarakat. ${ }^{60}$

Tugas penghormatan, perlindungan dan pemenuhan HAM selain kewajiban dan tanggung jawab pemerintah, juga memerlukan peran dan partisipasi dari masyarakat, ${ }^{61}$ sehingga melalui sinergi antara pihak, yaitu Pemerintah sebagai penyuluh dan penegak keadilan, institusi pendidikan dan pengajar yang berperan utama dalam meningkatkan mutu pendidikan, serta peran masyarakat yang diharapkan aktif dalam memajukan pendidikan dengan memberikan bantuan kepada sesama masyarakat yang membutuhkan ataupun pemberian umpan balik kepada pemerintah atas program-program yang telah dilakukan, maka pemenuhan hak asasi manusia di bidang pendidikan dapat diwujudkan secara merata di masa pandemi Covid-19.

\section{KESIMPULAN}

Berdasarkan uraian pada bab-bab sebelumnya, maka dapat ditarik dua simpulan berdasarkan analisis atas permasalahan. Pertama, pembelajaran jarak jauh di Indonesia telah memiliki dasar hukum yang sesuai dengan amanat Pancasila dan UUD NRI 1945, yaitu dalam UU Nomor 20 Tahun 2003 tentang Sistem Pendidikan Nasional, PP Nomor 17 Tahun 2010 tentang Pengelolaan dan Penyelenggaraan Pendidikan, Permendikbud Tahun 119 Tahun 2014 tentang Penyelenggaraan Pendidikan Jarak Jauh Pada Jenjang Pendidikan Dasar dan Menengah, serta SE Sekjen Kemendikbud Nomor 15 Tahun 2020 Pedoman Penyelenggaraan Belajar Dari Rumah dalam Masa Darurat Penyebaran Covid-19. Pembelajaran jarak

61 Tony Yuri Rahmanto, "Kebebasan Berekspresi Dalam Perspektif Hak Asasi Manusia: Perlindungan, Permasalahan Dan Implementasinya Di Provinsi Jawa Barat," Jurnal HAM 7, no. 1 (2016): 45-53. 
jauh (PJJ) memiliki makna "pendidikan yang peserta didiknya terpisah dari pendidik dan pembelajarannya menggunakan berbagai sumber belajar melalui teknologi komunikasi, informasi, dan media lain" sehingga tidak terbatas pada pembelajaran jauh secara daring saja, melainkan dapat menerapkan pemanfaatan teknologi lain seperti situs internet, siaran televisi atau buku elektronik, dimana pelaksanaannya harus mengedepankan nilai-nilai Pancasila.

Kedua, berdasarkan analisis tentang kesesuaian regulasi pendidikan jarak jauh dengan pengaturan hak asasi manusia di bidang pendidikan dalam konstitusi, regulasi tentang PJJ di Indonesia dalam undang-undang dan peraturan-peraturan di bawahnya telah menjunjung perlindungan dan pemenuhan atas HAM, yaitu sesuai dengan salah satu tujuan negara untuk mencerdaskan kehidupan bangsa sebagaimana tertulis dalam Pembukaan UUD 1945, serta sesuai juga dengan Pasal 28C dan Pasal 31 UUD 1945 yang mengatur hak-hak konstitusional warga negara di bidang pendidikan. UU Nomor 20 Tahun 2003 telah memberikan ruang untuk menentukan metode dan sarana pembelajaran yang dapat disesuaikan dengan kondisi ekonomi dan sosial masingmasing institusi pendidikan maupun peserta didik dalam pelaksanaan pembelajaran jarak jauh.

Pembelajaran jarak jauh yang sesuai dengan upaya pemenuhan hak atas pendidikan di Indonesia pada masa covid-19 adalah pembelajaran yang telah berfokus kepada hakekat pendidikan nasional itu sendiri, yaitu pendidikan yang berdasarkan grundnorm Pancasila dan pasal-pasal UUD NRI 1945 dan UU Nomor 20 Tahun 2003 yang menekankan bahwa Pendidikan harus dilaksanakan secara demokratis, berkeadilan, tidak diskriminatif dan menjunjung tinggi HAM, nilai keagamaan, nilai kultural dan kemajemukan, serta tetap mengikuti perkembangan teknologi informasi, yang pelaksanaannya melibatkan sinergi antara pemerintah, institusi pendidikan dan masyarakat dengan semangat gotong royong.

\section{SARAN}

Agar pembelajaran jarak jauh dapat dilaksanakan secara optimal dan mencerminkan keadilan sosial, pemerintah pusat dan daerah dapat melakukan sosialisasi kepada institusi pendidikan, pengajar atau guru dan masyarakat luas mengenai pengertian PJJ itu sendiri yang sesuai dengan pengertian dalam UU Nomor 20
Tahun 2003, sehingga miskonsepsi PJJ sebagai pembelajaran yang terbatas melalui panggilan video (video call/video conference) antara guru dengan siswa, ataupun PJJ sebagai sistem pembelajaran yang tugas-tugas dan pekerjaan rumahnya harus dikumpulkan secara daring melalui aplikasi tertentu dapat diluruskan kembali sesuai dengan maksud pembuat undang-undang. Disamping itu, pembuatan buku panduan untuk melaksanakan PJJ bagi institusi pendidikan dapat dilakukan.

Kemudian, penggunaan teknologi informasi dan komunikasi dapat dimanfaatkan tidak hanya untuk panggilan video atau sarana pengiriman tugas dari guru ke murid dan sebaliknya. Aplikasi penyimpanan data, seperti dropbox, google drive dan sebagainya dapat dimanfaatkan sebagai perpustakaan digital oleh sekolah, yang dapat diakses dari luar sekolah oleh siswa, dan memungkinkan untuk dicetak dalam bentuk hardcopy untuk dipelajari. Lalu, dana BOS maupun dana lainnya yang telah disediakan untuk menunjang PJJ di masa Covid-19 untuk pembelian kuota internet dan aplikasi pembelajaran, dapat juga digunakan untuk membiayai pembelian alat tulis dan perlengkapan lain bagi siswa untuk mengerjakan tugas secara kreatif dan mandiri. Evaluasi pendidikan secara berkala dengan mempertimbangkan kondisi geografis, ekonomi dan sosial institusi pendidikan, pengajar, dan siswa juga perlu dilakukan untuk dapat menyempurnakan kebijakan PJJ yang sedang berjalan.

Terakhir perlu dilakukan upaya-upaya untuk mendorong pemerintah daerah dan satuan pendidikan dibawahnya untuk melaksanakan kegiatan pendataan atas ketersediaan akses internet dan listrik, serta data kondisi, kesiapan, dan kebutuhan belajar bagi para peserta didik, termasuk data jumlah dan sebaran peserta didik yang tidak memiliki akses sarana dan pembelajaran daring. Sehingga kedepannya dapat diputuskan metode PJJ seperti apa yang tepat untuk diterapkan di daerahnya masing-masing.

\section{UCAPAN TERIMA KASIH}

Terima kasih saya ucapkan kepada pimpinan yang terkasih, Dr. iur Asmin Fransiska, S.H., LL.M., selaku Dekan Fakultas Hukum Unika Atma Jaya Jakarta dan Bapak Johanes de Britto Sardadi Sambada, S.H., 
M.Hum. selaku Wakil Dekan sekaligus pengajar Hukum Tata Negara yang telah mendukung penulis dalam pembuatan penulisan ini.

\section{DAFTAR PUSTAKA}

Adit, Albertus. "12 Aplikasi Pembelajaran Daring Kerjasama Kemendikbud, Gratis!" Last modified 2020. Accessed July 19, 2020.

https:/edukasi.kompas.com/read/2020/03/ 22/123204571/12-aplikasi-pembelajarandaring-kerjasama-kemendikbudgratis?page $=$ all.

Arifah, Risqi Ervera Nur, Sukirman, and Sujalwo. "Pengembangan Game Edukasi Bilomatika Untuk Meningkatkan Hasil Belajar Siswa Pada Mata Pelajaran Matematika Kelas 1 SD.” Jurnal Teknologi Informasi dan Ilmu Komputer Universitas Brawijaya 6, no. 6 (2019): 617-624.

Asshiddiqie, Jimly. Pengantar Ilmu Hukum Tata Negara. 1st ed. Jakarta: Rajawali Pers, 2013.

Budiman, Arief. Teori Negara: Negara, Kekuasaan Dan Ideologi. Jakarta: Gramedia Pustaka Utama, 1996.

CNBC Indonesia. "Nonton TVRI Online \& Jadwal Belajar Dari Rumah Anak Sekolah." Last modified April 14, 2020. Accessed July $19, \quad 2020$. https://www.cnbcindonesia.com/tech/2020 0414144619-37-151832/nonton-tvrionline-jadwal-belajar-dari-rumah-anaksekolah.

Hadjon, Philipus M. "Hukum Administrasi Sebagai Instrumen Hukum Untuk Mewujudkan Good Governance."' In Hukum Administrasi Dan Good Governance. Jakarta: Penerbit Universitas Trisakti, 2010.

Huijbers, Theo. Filsafat Hukum Dalam Lintasan Sejarah. Yogyakarta: Penerbit Kanisius, 1982.

Ibrahim, Johnny. Teori Dan Metodologi Penelitian Hukum Normatif. Malang: Bayumedia Publishing, 2008.

Isdiyanto, Ilham Yuli. 'Menakar 'Gen' Hukum Indonesia Sebagai Dasar Pembangunan Hukum Nasional." Jurnal Hukum dan Pembangunan 48, no. 3 (2018): 589-611.

Jalil, Aria. "Pembelajaran Jarak Jauh." Jurnal Ilmu Pendidikan Universitas Negeri Malang 1, no. 1 (1994): 22-43.

Kelsen, Hans. The Pure Theory of Law.
California: University of California Press, 1967.

Kementerian Pendidikan dan Kebudayaan, Kementerian Agama, Kementerian Kesehatan, and Kementerian Dalam Negeri. "Keputusan Bersama Tanggal 15 Juni 2020 Tentang Panduan Penyelenggaraan Pembelajaran Pada Tahun Ajaran Dan Tahun Akademik Baru Di Masa Pandemi Covid-19." In Keputusan Bersama Tanggal 15 Juni 2020 Tentang Panduan Penyelenggaraan Pembelajaran Pada Tahun Ajaran Dan Tahun Akademik Baru Di Masa Pandemi Covid-19. Jakarta, 2020.

Kementerian Pendidikan dan Kebudayaan RI. "Mendikbud Kembali Tegaskan Pembukaan Sekolah Di Zona Hijau Harus Mengedepankan Protokol Kesehatan." Last modified 2020. Accessed July 19, 2020. https://www.kemdikbud.go.id/main/blog /2020/07/mendikbud-kembali-tegaskanpembukaan-sekolah-di-zona-hijauharus-mengedepankan-protokolkesehatan.

Komisi Perlindungan Anak Indonesia. Hanya 8 Persen Guru Yang Paham Gawai Untuk Pembelajaran Daring. Jakarta, 2020.

https://www.kpai.go.id/berita/hanya-8guru-yang-paham-gawai-untukpembelajaran-daring.

Kusuma, RM A.B. Sistem Pemerintahan Pendiri Negara versus Sistem Presidensiel Orde Reformasi. Depok: Badan Penerbit Fakultas Hukum Universitas Indonesia, 2011.

MacKenzie, O., E. Christensen, and Rigby P.H. Correspondence Instruction in the United States: A Study of What It Is, How It Functions, and What Its Potential May $B e$. New York: McGraw-Hill Book Co., 1968.

Mawardi, Irvan. Paradigma Baru PTUN Respon Peradilan Administrasi Terhadap Demokrasi. Yogyakarta: Thafa Media, 2016.

Menteri Pendidikan dan Kebudayaan RI. Peraturan Menteri Nomor 119 Tahun 2014 Tentang Penyelenggaraan Pendidikan Jarak Jauh Pada Jenjang Pendidikan Dasar Dan Menengah, 2014. - Peraturan Menteri Pendidikan Dan Kebudayaan Nomor 119 Tahun 2014 
Tentang Penyelenggaraan Pendidikan Jarak Jauh Pada Jenjang Pendidikan Dasar Dan Menengah, 2014.

Michael, Donny. "Penyelenggaraan Pendidikan Tinggi Bagi Penyandang Disabilitas Di Universitas Brawijaya." Jurnal HAM 11, no. 2 (2020): 201-217.

Moore, M.G. "Toward a Theory of Independent Learning and Teaching." Journal of Higher Education 44 (1973): 66-79.

Munir. Pembelajaran Jarak Jauh Berbasis Teknologi Informasi Dan Komunikasi. Bandung: Alfabeta, 2009.

Nurdin, Irfan Rahman. "Penerapan Sistem Pembelajaran Jarak Jauh Berbasis Massive Open Online Course (MOOC) Di Universitas Ciputra Enterpreunership Online (UCEO)." Universitas Negeri Semarang, 2017.

Oktawirawan, Dwi Hardani. "Faktor Pemicu Kecemasan Siswa Dalam Melakukan Pembelajaran Daring Di Masa Pandemi Covid-19." Jurnal Ilmiah Universitas Batanghari Jambi 20, no. 2 (2020): 541544.

Prasasti, Giovani Dio. "UNESCO: Penutupan Sekolah Akibat COVID-19 Berdampak Pada 290 Juta Pelajar Di Dunia Pendidikan." Last modified 2020. Accessed July 19, 2020. https://www.liputan6.com/health/read/419 5275/unesco-penutupan-sekolah-akibatcovid-19-berdampak-pada-290-jutapelajar-di-dunia.

Prasetyo, Hoedi, and Wahyudi Sutopo. "Industri 4.0: Telaah Klasifikasi Aspek Dan Arah Perkembangan Riset." Jurnal Teknologi dan Informasi (J@TI) UNDIP 13, no. 1 (2018): 17-26.

Prawiyogi, Anggy Giri, Andri Purwanugraaha, Ghulam Fakhry, and Marwan Firmansyah. "Efektivitas Pembelajaran Jarak Jauh Terhadap Pembelajaran Siswa Di SDIT Cendektia Purwakarta." Jurnal Pendidikan Dasar UNJ 11, no. 1 (2020).

Rahmanto, Tony Yuri. "Kebebasan Berekspresi Dalam Perspektif Hak Asasi Manusia: Perlindungan, Permasalahan Dan Implementasinya Di Provinsi Jawa Barat." Jurnal HAM 7, no. 1 (2016): 45-53.

Republik Indonesia. Peraturan Pemerintah Nomor 17 Tahun $2010 \quad$ Tentang Pengelolaan Dan Penyelenggaraan Pendidikan, 2010.

- Undang-Undang Dasar Negara

Amandemen), n.d.

- Undang-Undang No. 39 Tahun 1999

Tentang Hak Asasi Manusia, 1999.

- Undang-Undang Nomor 20 Tahun 2003 Tentang Sistem Pendidikan Nasional, 2003.

Rigianti, Henry Aditia. "Kendala Pembelajaran Daring Guru Sekolah Dasar Di Kabupaten Banjarnegara." Jurnal Elementary School Univeritas PGRI Yogyakarta Indonesia 7, no. 2 (2020): 297-302.

Rozak, Abdul. "Perlindungan Hak Atas Pendidikan Bagi Pengungsi Internal: Studi Kasus Pendidikan Anak Korban Kekerasan Terhadap Warga Syiah Sampang." Juris-Diction 2, no. 6 (2019): 1987-1908.

Sekretaris Jenderal Kemendikbud RI. Surat Edaran Sekretaris Jenderal Kemendikbud Tentang Pedoman Penyelenggaraan Belajar Dari Rumah Dalam Masa Darurat Penyebaran Covid-19 Nomor 15 Tahun 2020. Jakarta: Kemendikbud RI, 2020.

Sessu, Hasmiati. "Evaluasi Penyelenggaraan Pendidikan Jarak Jauh Bagi Tenaga Bidan Lulusan Diploma I Kebidanan Di Poltekkes Kemenkes Kupang Tahun 2015." Universitas Indonesia, 2015.

Smith, Rhona K.M., Njal Hostmaelingen, Christian Ranheim, Satya Arinanto, Fajrul Falaakh, and Enny Soeprapto. Hukum Hak Asasi Manusia. 3rd ed. Yogyakarta: PUSHAM UII, 2015.

Soekanto, Soerjono, and Sri Mamudji. Penelitian Hukum Normatif: Suatu Tinjauan Singkat. Jakarta: Rajawali Pers, 2013.

UNICEF. "Indonesia: Survei Terbaru Menunjukkan Bagaimana Siswa Belajar Dari Rumah (Hampir 9 Dari 10 Responden Mengatakan Mereka Ingin Segera Kembali Ke Sekolah)." Last modified 2020. Accessed August 20, 2020.

https://www.unicef.org/indonesia/id/pres s-releases/indonesia-survei-terbarumenunjukkan-bagaimana-siswa-belajardari-rumah.

United Nations. "Universal Declaration of Human Rights," 1948.

Utama, Farhan Abdi. "Meritokrasi Di Berbagai Negara Dunia." Jurnal Civil Service Badan Kepegawaian Negara 10, no. 2 (2016): 17-27. 
KOSONG 